\title{
Mesoporous carbons as metal-free catalysts for propane dehydrogenation: Effect of the pore structure and surface property
}

\author{
Zhong-Pan Hu a, Jin-Tao Ren a, Dandan Yang a, Zheng Wang b, Zhong-Yong Yuan a,* \\ a Key Laboratory of Advanced Energy Materials Chemistry (Ministry of Education), School of Materials Science and Engineering, Nankai University, \\ Tianjin 300350, China \\ ${ }^{\mathrm{b}}$ State Key Laboratory of High-efficiency Utilization of Coal and Green Chemical Engineering, College of Chemistry and Chemical Engineering, Ningxia \\ University, Yinchuan 750021, Ningxia, China
}

\section{A R T I C L E I N F O}

\section{Article history:}

Received 20 January 2019

Accepted 25 February 2019

Published 5 September 2019

\section{Keywords:}

Mesoporous carbons

Propane

Dehydrogenation

Propylene

Metal-free catalysis

\begin{abstract}
A B S T R A C T
Nanocarbon materials have been used as important metal-free catalysts for various reactions including alkane dehydrogenation. However, clarifying the active sites and tuning the nanocarbon structure for direct dehydrogenation have always been significantly challenging owing to the lack of fundamental understanding of the structure and surface properties of carbon materials. Herein, mesoporous carbon materials with different pore ordering and surface properties were synthesized through a soft-templating method with different formaldehyde/resorcinol ratios and carbonization temperatures and used for catalytic dehydrogenation of propane to propylene. The highly ordered mesoporous carbons were found to have higher catalytic activities than disordered and ordered mesoporous carbons, mainly because the highly ordered mesopores favor mass transportation and provide more accessible active sites. Furthermore, mesoporous carbons can provide a large amount of surface active sites owing to their high surface areas, which is favorable for propane dehydrogenation reaction. To control the surface oxygenated functional groups, highly ordered mesoporous carbons were carbonized at different temperatures $\left(600,700\right.$, and $\left.800{ }^{\circ} \mathrm{C}\right)$. The propylene formation rates exhibit an excellent linear relationship with the number of ketonic $\mathrm{C}=0$ groups, suggesting that $\mathrm{C}=0$ groups are the most possible active sites.
\end{abstract}

(C) 2019, Dalian Institute of Chemical Physics, Chinese Academy of Sciences. Published by Elsevier B.V. All rights reserved.

\section{Introduction}

Nanocarbons, such as graphene, nanodiamond, carbon nanotubes, activated carbons, and nanoporous carbons, are important metal-free catalysts for various catalytic reactions, including oxidative dehydrogenation [1-3], direct dehydrogenation [4-6], electrocatalysis [7,8], oxidation $[9,10]$, and reactions in supercapacitors [11]. These nanocarbons possess many advantages such as high thermal stability, good conduc- tivity, large porosity, and tunable functional groups, in comparison with traditional metal and metal oxide catalysts. However, studies on the active sites and catalytic mechanisms of nanocarbons are progressing slowly owing to their complex structure and the presence of various surface functional groups.

Recently, surface oxygenated functional groups are found to be the active sites of nanocarbons in oxidative dehydrogenation reaction, wherein the carbonyl groups acting as electron

\footnotetext{
* Corresponding author. Tel/Fax: +86-22-23509610; E-mail: zyyuan@nankai.edu.cn

This work was supported by the National Natural Science Foundation of China (21421001, 21573115), the Fundamental Research Funds for the Central Universities (63185015), and the Foundation of State Key Laboratory of High-efficiency Utilization of Coal and Green Chemical Engineering (2017-K13).

DOI: S1872-2067(19)63334-6 | http://www.sciencedirect.com/science/journal/18722067 | Chin. J. Catal., Vol. 40, No. 9, September 2019
} 
donors could active the $\mathrm{C}-\mathrm{H}$ bonds [12-15]. Qi et al. [16,17] identified and quantified the active sties of nanocarbon catalysts in ethylbenzene oxidative dehydrogenation by a chemical titration method, further demonstrating that the carboxyl groups were the main active sites. Further, carbon composite catalysts were reported to be active in direct ethylbenzene dehydrogenation [18-20]. All the surface oxygenated functional groups, defects, and heteroatom-derived groups make good contribution to the catalytic dehydrogenation. Moreover, biomass-derived carbon catalysts with rich oxygenated functional groups and high porosity are reported to exhibit high catalytic activity and stability in propane dehydrogenation (PDH) $[21,22]$. However, the catalytic mechanism and active sites of these carbon catalysts in the direct dehydrogenation of alkane have not been totally clarified owing to the lack of fundamental studies on the nanocarbon materials at high reaction temperatures $\left(\sim 600^{\circ} \mathrm{C}\right)$.

Meanwhile, the structural property of carbon catalysts can influence the mass transfer of reactant and product molecules, and thus affect their catalytic performance [23-28]. Matos et al. [29] reported that the pore size of activated carbon supports (i.e., $0.8 \mathrm{~nm}$ for $\mathrm{AC}_{\mathrm{M}}$ and $1.9 \mathrm{~nm}$ for $\mathrm{AC}_{\mathrm{PC}}$ ) could affect the catalytic performance of NiMo catalysts in ethylene hydrogenation; the catalytic stability of $\mathrm{NiMo/ACM} \mathrm{was} \mathrm{found} \mathrm{to} \mathrm{be} \mathrm{much} \mathrm{better}$ than that of $\mathrm{NiMo} / \mathrm{AC}_{\mathrm{PC}}$, because the activated carbon support with a smaller pore size permitted higher tolerance to carbon deposits. According to recent reports, only ordered carbons exhibit outstanding long-term stability in oxidative dehydrogenation reactions [30,31]. Mesoporous carbons with a highly ordered structure exhibited superior catalytic performance in the oxidative dehydrogenation of ethylbenzene to styrene [31]. Very recently, heteroatom-doped mesoporous carbons with rich oxygenated functional groups and well-defined mesopores were reported to exhibit high catalytic performance in dehydrogenation reactions [32,33]. However, the influence of the pore ordering on the catalytic performance of mesoporous carbons in PDH has not been investigated yet, owing to the lack of appropriate methods to prepare mesoporous carbons with controlled porous structures.

Herein, disordered, ordered, and highly ordered mesoporous carbons (MCs) were synthesized through a soft-templating method. The channels of the mesoporous carbons were controlled by adjusting the formaldehyde/resorcinol molar ratio. Then, the highly ordered mesoporous carbons were carbonized at three different temperatures $\left(600,700\right.$, and $\left.800{ }^{\circ} \mathrm{C}\right)$ and their activities in $\mathrm{PDH}$ were tested. The properties of these carbon materials were characterized by X-ray diffraction (XRD), $\mathrm{N}_{2}$ sorption, transmission electron microscopy (TEM), thermogravimetric analysis (TGA), and X-ray photoelectron spectroscopy (XPS). Furthermore, the relationship between the oxygenated functional groups and propylene formation rates was established.
Mesoporous carbons were prepared through a facile low-temperature autoclaving method with the assistance of soft templates. Typically, $2.5 \mathrm{~g}$ of Pluronic F127 (BASF, WPAJ508B) was dissolved in $40 \mathrm{~mL}$ of ethanol/deionized water (1:1). Then, formaldehyde solution (37 wt\%, $2.5 \mathrm{~g}$ ), citric acid ( $2.9 \mathrm{~g})$, and resorcinol $(1.65 \mathrm{~g})$ were added to the solution. After stirring for $1 \mathrm{~h}$, the mixture was loaded into a Teflon-lined autoclave and heated at $60^{\circ} \mathrm{C}$ for $72 \mathrm{~h}$. After this time, a polymeric block solid was formed; this was washed with plenty of water and subsequently dried at $80^{\circ} \mathrm{C}$ for $24 \mathrm{~h}$. Then, the dried sample was carbonized under $\mathrm{N}_{2}$ flow (heating rate, $1^{\circ} \mathrm{C} / \mathrm{min}$ ) and heated at $600{ }^{\circ} \mathrm{C}$ for $2 \mathrm{~h}$. The resultant sample is denoted as MC-2-600 (the formaldehyde/resorcinol molar ratio of this sample is 2:1). The carbons prepared with the formaldehyde/resorcinol ratios of $1: 1,3: 1$, and $4: 1$, are denoted as MC- $x-600$ ( $x$ represents the formaldehyde ratio). For comparison, MC-2-600 was synthesized without adding Pluronic F127 and the resulting sample is referred to as MC-0-600.

The polymeric block solids (formaldehyde/resorcinol ratio is 2:1) carbonized under $\mathrm{N}_{2}$ flow (heating rate, $1^{\circ} \mathrm{C} / \mathrm{min}$ ) and heated at 700 and $800{ }^{\circ} \mathrm{C}$ for $2 \mathrm{~h}$ are referred to as MC-2-y $(y$ represents the carbonization temperature). Furthermore, as-synthesized MC-2-800 was oxidized with $\mathrm{HNO}_{3}(6 \mathrm{~mol} / \mathrm{L})$ for $2 \mathrm{~h}$ and the resulting sample is denoted as MCO-2-800.

\subsection{Characterization}

XRD was carried out on a Bruker D8 Focus diffractometer using $\mathrm{Cu}-K_{\alpha}$ radiation $(\lambda=1.5418 \AA$. $40 \mathrm{kV}, 40 \mathrm{~mA})$. Nitrogen sorption isotherms were recorded on a Quantachrome NOVA 2000 e sorption analyzer. All the samples were degassed at 200 ${ }^{\circ} \mathrm{C}$ for more than $6 \mathrm{~h}$. TEM was carried out on a Jeol JEM-2800 microscope at $200 \mathrm{kV}$. TGA was performed on a TA SDT Q600 instrument. XPS was performed on a Kratos Axis Ultra DLD spectrometer. All the spectra were modified with reference to $\mathrm{C}$ $1 s$ at $284.8 \mathrm{eV}$.

\subsection{Catalytic testing}

The PDH tests were carried out in a fixed-bed micro-reactor at atmospheric pressure. During the catalytic reaction, $0.2 \mathrm{~g}$ of the catalyst (450-950 $\mu \mathrm{m})$ was packed into a tubular quartz reactor ( $5 \mathrm{~mm}$ internal diameter). The reactant gas consisted of propane $\left(\mathrm{C}_{3} \mathrm{H}_{8}\right)$ and nitrogen $\left(20 \mathrm{~mL} / \mathrm{min}, V_{\text {propane: }} V_{\text {nitrogen }}=\right.$ 1:19). The gas flow rate was $6000 \mathrm{~mL} /\left(\mathrm{g}_{\text {cat }} \cdot \mathrm{h}\right)$. The products were detected by on-line gas chromatography (GC, SP-6890, FID detector). Propane conversion and propylene selectivity were calculated as follows:

$\mathrm{C}_{3} \mathrm{H}_{8}$ conversion $(\mathrm{mol} \%)=$ moles of $\mathrm{C}_{3} \mathrm{H}_{8}$ reacted $/$ moles of $\mathrm{C}_{3} \mathrm{H}_{8}$ fed $\times 100$

$\mathrm{C}_{3} \mathrm{H}_{6}$ selectivity $(\mathrm{mol} \%)=$ moles of product $\mathrm{C}_{3} \mathrm{H}_{6}$ formed $/$ moles of $\mathrm{C}_{3} \mathrm{H}_{8}$ reacted $\times 100$

\section{Results and discussion}

\subsection{Structural and textural properties of the catalysts}

\subsection{Synthesis}



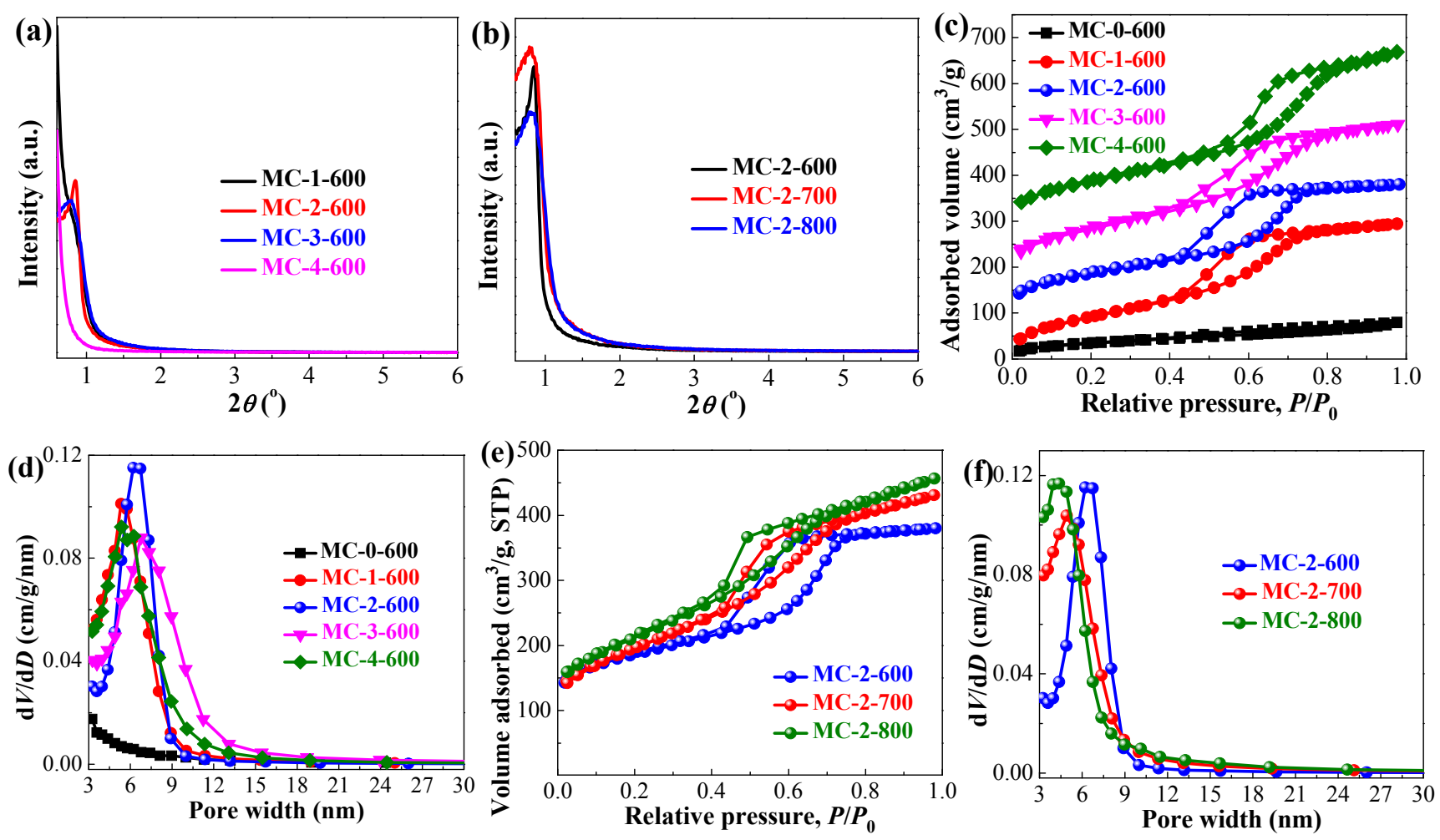

Fig. 1. Low-angle XRD patterns (a,b), $\mathrm{N}_{2}$ adsorption-desorption isotherms (c,e), and the corresponding BJH pore size distribution curves (d,f) of MCs. The $\mathrm{N}_{2}$ sorption isotherms of MC-2-600, MC-3-600, and MC-4-600 in Fig. 1(c) are offset by 100, 200, and 300 $\mathrm{cm}^{3} / \mathrm{g}$, respectively.

Resorcinol-formaldehyde resin is known to be a good carbon precursor for preparing mesoporous carbons [34-38]. The formation of resin polymers is strongly dependent on the interaction between the resorcinol-formaldehyde resin and Pluronic F127, wherein the hydroxyl groups in the resole provide the driving force for interactions with the PEO blocks of Pluronic F127 through hydrogen bonding [34,37]. Particularly, the macroscopic phase separation of the carbon precursor/F127 solid composites from the ethanol/water solvent is a key step in the preparation of ordered mesoporous carbons [37,38]. The formaldehyde/resorcinol ratio plays a critical role in the regulation of the phase separation processes [24,38]. To investigate the effect of formaldehyde/resorcinol ratio and the calcination temperature, carbon materials with different formaldehyde/resorcinol molar ratios were synthesized and subsequently calcined at different temperature.
As shown in the low-angle XRD patterns (Fig. 1(a)), MC-2-600 and MC-3-600 possess an obvious diffraction peak at $2 \theta=0.85^{\circ}$ and $0.78^{\circ}$, respectively, which can be indexed to (100) diffraction, characteristic of hexagonal $p 6 \mathrm{~mm}$ mesophase symmetry [25,39]. However, MC-1-600 and MC-4-600 display almost no diffraction peaks. As for MC-2-y (Fig. 1(b)), their XRD patterns possess a clear diffraction peak, indicating a highly ordered mesostructure. The porosities of MCs are determined by $\mathrm{N}_{2}$ sorption analysis (Fig. 1(c)-(f) and Table 1). MC-0-600 (prepared without Pluronic F127) exhibits a characteristic type III sorption isotherm with a low surface area of $126 \mathrm{~m}^{2} / g$. With the addition of Pluronic F127, the $\mathrm{N}_{2}$ sorption isotherms of MC- $x-600$ change to type IV with a hysteresis loop of type H1, characteristic of mesoporous materials $[40,41]$. A step at $P / P_{0}=$ $0.5-0.7$ can be observed in the isotherm of MC- $x-600$, which is attributed to the filling of mesopores due to capillary force

Table 1

Structural properties and catalytic performance of MCs.

\begin{tabular}{|c|c|c|c|c|c|c|c|}
\hline Sample & $\begin{array}{c}S_{\mathrm{BET}^{\mathrm{a}}} \\
\left(\mathrm{m}^{2} / \mathrm{g}\right) \\
\end{array}$ & $\begin{array}{c}V_{\text {total }}{ }^{\mathrm{b}} \\
\left(\mathrm{cm}^{3} / \mathrm{g}\right)\end{array}$ & $\begin{array}{l}D_{\text {DFT }}{ }^{\mathrm{c}} \\
(\mathrm{nm})\end{array}$ & $\begin{array}{l}D_{\mathrm{BJH}}{ }^{\mathrm{d}} \\
(\mathrm{nm})\end{array}$ & $\begin{array}{c}\text { Propane conversion }{ }^{\mathrm{e}} \\
(\%)\end{array}$ & $\begin{array}{c}\text { Propylene selectivity e } \\
(\%)\end{array}$ & $\begin{array}{l}\text { Specific activity } \\
\left(\mu \mathrm{mol} /\left(\mathrm{m}^{2} \cdot \mathrm{g} \cdot \mathrm{h}\right)\right)\end{array}$ \\
\hline MC-0-600 & 126 & 0.13 & - & - & $6.4(5.5)$ & $84.1(87.2)$ & 28.8 \\
\hline MC-1-600 & 635 & 0.61 & 4.1 & 5.3 & 28.7 (23.9) & $86.8(90.4)$ & 26.3 \\
\hline MC-2-600 & 604 & 0.60 & 4.1 & 6.6 & $35.7(28.1)$ & $85.6(89.4)$ & 33.9 \\
\hline MC-3-600 & 621 & 0.73 & 4.5 & 6.7 & $35.5(27.6)$ & $86.6(90.1)$ & 33.2 \\
\hline MC-4-600 & 615 & 0.64 & 4.9 & 6.2 & $25.9(21.0)$ & $89.1(91.8)$ & 25.1 \\
\hline MC-2-700 & 669 & 0.67 & 3.9 & 4.9 & $22.8(18.9)$ & 88.7 (91.1) & 20.2 \\
\hline MC-2-800 & 727 & 0.71 & 3.8 & 4.4 & $14.9(14.0)$ & $93.5(94.5)$ & 12.8 \\
\hline MCO-2-800 & 655 & 0.57 & 3.8 & 4.9 & $34.8(18.6)$ & $88.9(92.4)$ & 31.6 \\
\hline
\end{tabular}

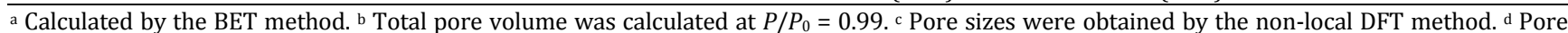
sizes were obtained by the BJH method. e Data in the parentheses correspond to the used catalysts after $10 \mathrm{~h}$ time-on-stream. 
$[38,40]$. In Fig. 1(d), narrow pore size distributions can be observed for the MC- $x-600$ samples, and their pore sizes (calculated by BJH method) are mainly distributed in the 3-9 $\mathrm{nm}$ range. Particularly, the pore size distribution curve of MC-2-600 is narrower than those of the other samples, indicating the presence of more uniform pores in it [38]. The BET surface areas and pore volumes of MC-1-600, MC-2-600, MC-3-600, and MC-4-600 are higher than $600 \mathrm{~m}^{2} / \mathrm{g}$ and 0.60 $\mathrm{cm}^{3} / \mathrm{g}$, respectively. Fig. 1(e) and (f) shows the $\mathrm{N}_{2}$ sorption results of MC-2-y carbonized at different temperatures. The adsorbed $\mathrm{N}_{2}$ volumes of MC-2-y increase with an increase in the calcination temperature, while their pore diameter decreases with increasing calcination temperature: MC-2-600 $\left(604 \mathrm{~m}^{2} / \mathrm{g}\right.$, $\left.0.60 \mathrm{~cm}^{3} / \mathrm{g}\right)$, MC-2-700 (669 m² $\left./ \mathrm{g}, 0.67 \mathrm{~cm}^{3} / \mathrm{g}\right)$, and MC-2-800 $\left(727 \mathrm{~m}^{2} / \mathrm{g}, 0.71 \mathrm{~cm}^{3} / \mathrm{g}\right.$ ), respectively. All the MC-2-y samples possess a narrow pore size distribution. Particularly, the mean pore sizes of MC-2-700 (4.9 nm) and MC-2-800 (4.4 nm) are slightly smaller than that of MC-2-600 (6.7 nm).

The micromorphology of MCs can be directly observed by TEM, as shown in Figs. 2 and S3. Notably, MC-2-600 and MC-3-600 display highly ordered mesopores (Fig. 2(a)-(c)). In particular, MC-2-600 presents a much better ordered long-range hexagonal arrangement with a pore size of $\sim 6.5 \mathrm{~nm}$, in good agreement with the $\mathrm{N}_{2}$ sorption results (Fig. 1(d)). MC-1-600 (Fig. 2(d)) and MC-4-600 (Fig. 2(e)) show worm-like pores with poor ordering. Fig. 2(f) displays the TEM image of MC-0-600 with no obvious pores, indicating that Pluronic F127 plays a key role in the formation of mesopores. The pore ordering of MCs can be controlled by adjusting the formalde-

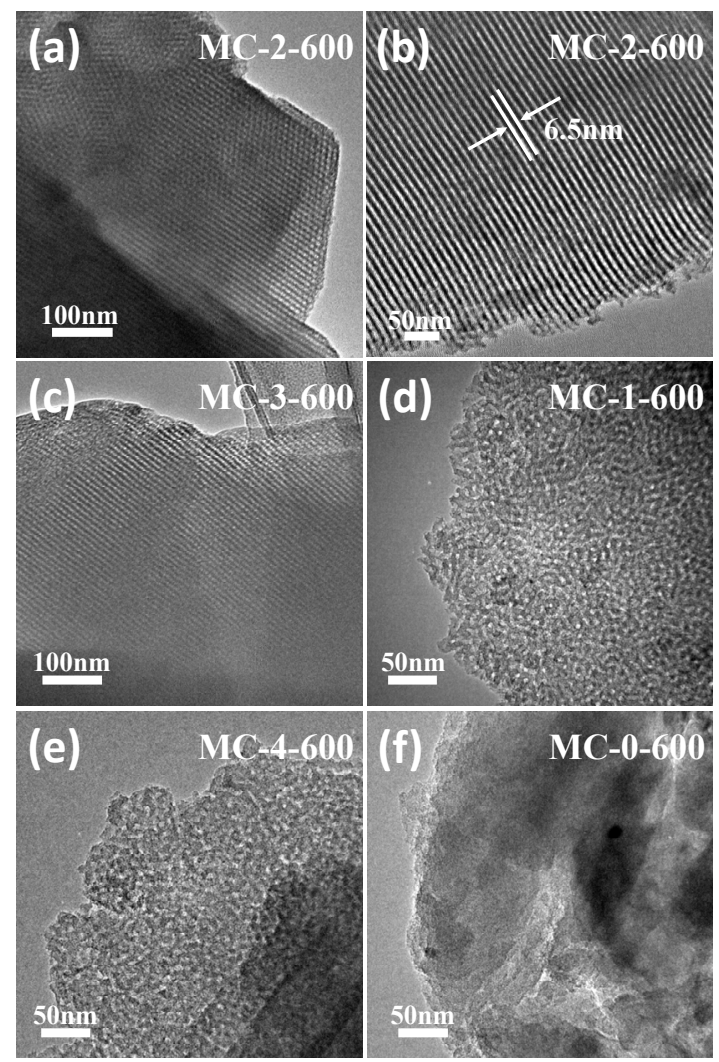

Fig. 2. TEM images of MCs. (a, b) MC-2-600; (c) MC-3-600; (d) MC-1-600; (e) MC-4-600; (f) MC-0-600. hyde/resorcinol ratio (Fig. S2). The TEM images of MC-2-700 and MC-2-800 in Fig. S3 exhibit a well-ordered mesoporous structure. This illustrates that the carbonization temperature $\left(600-800{ }^{\circ} \mathrm{C}\right)$ has little influence on the pore ordering of MCs, in good agreement with the XRD results in Fig. 1(b).

\subsection{Surface oxygenated functional groups}

Carbon materials are known to possess many surface oxygenated functional groups such as ketone, carboxylic anhydride, lactone, carboxylic acid, ether, and phenol. The type and concentration of these functional groups can be controlled by post thermal treatment [42-46]. At a low carbonization temperature $\left(\sim 400{ }^{\circ} \mathrm{C}\right)$, carboxylic anhydride groups would decompose $[42,43]$. In the temperature range of $400-600{ }^{\circ} \mathrm{C}$, the main oxygenated functional groups including phenol and lactone groups would decompose. When the carbonization temperature is higher than $600{ }^{\circ} \mathrm{C}$, the main oxygenated functional groups including phenol, lactone, and carbonyl/quinone groups would progressively decompose at elevated carbonization temperatures [44-46]. As shown in Fig. 3(a) and Table 2, the TG curve of MC-2-600 shows a large weight loss of $8.4 \%$ between 600 and $1000{ }^{\circ} \mathrm{C}$. Upon increasing the carbonization temperature to 700 and $800{ }^{\circ} \mathrm{C}$, the weight losses of MC-2-700 and MC-2-800 are $3.2 \%$ and $1.7 \%$, respectively, revealing a decrease in the surface functional groups with an increase in the carbonization temperature. Fig. S4 shows the TG curves of MC-2- $y$ recorded in air atmosphere. The half oxidation temperatures of MC-2-600, MC-2-700, and MC-2-800 are 530.3, 560.6, and $601.0^{\circ} \mathrm{C}$, respectively, indicating a decrease in the anti-oxidation properties of MCs with increasing carbonization temperature. The detailed trends of the weight losses and half oxidation temperatures of MC-2-y as a function of carbonization temperature are shown in Fig. 3(b). The weight losses of MC-2-y decrease with increasing carbonization temperature. These results demonstrate that the carbonization temperature can significantly affect the concentration of oxygenated functional groups on carbon materials.

The survey XPS spectrum reveals that the main elements in MC-2- $y$ are $\mathrm{C}$ and $\mathrm{O}$ (Fig. S5(a)). The 0 contents over MC-2-600, MC-2-700, and MC-2-800 are $8.3 \%, 6.1 \%$, and 5.1\%, respectively, in good agreement with the TG results (Fig. 3(a)). The 0 $1 s$ XPS spectrum can be fitted with three peaks (Fig. 3(c)) corresponding to $\mathrm{C}=\mathrm{O}(531.5-532.2 \mathrm{eV}), \mathrm{O}=\mathrm{C}-\mathrm{O}(532.5-533.0 \mathrm{eV})$, and $\mathrm{OH}(533.5-534.5 \mathrm{eV})$, respectively $[30,47,48]$. The $\mathrm{C} 1 \mathrm{~s}$ spectra can be deconvoluted into five peaks at $\sim 284.8 \mathrm{eV}$ (C-C/C-H), $\sim 286.2 \mathrm{eV}(\mathrm{C}-\mathrm{OH}), \sim 286.9 \mathrm{eV}(\mathrm{C}=0), 289.0 \mathrm{eV}$ $(\mathrm{COOH})$, and $291.2 \mathrm{eV}\left(\pi \rightarrow \pi^{*}\right)$, respectively (Fig. S5(b)-(d)) $[22,29]$. The proportions of these oxygenated functional groups are in good agreement with the oxygen contents estimated from the $01 s$ spectra. The total $\mathrm{O}$ and $\mathrm{C}=0$ contents as a function of carbonization temperature reveals that the concentrations of various oxygenated functional groups decrease with increasing carbonization temperature (Fig. 3(d)). However, there is no obvious linear relationship between the $\mathrm{O}=\mathrm{C}-\mathrm{O}$ and $\mathrm{OH}$ contents and carbonization temperature (Fig. S6).

The TG and XPS results demonstrate that the type and con- 

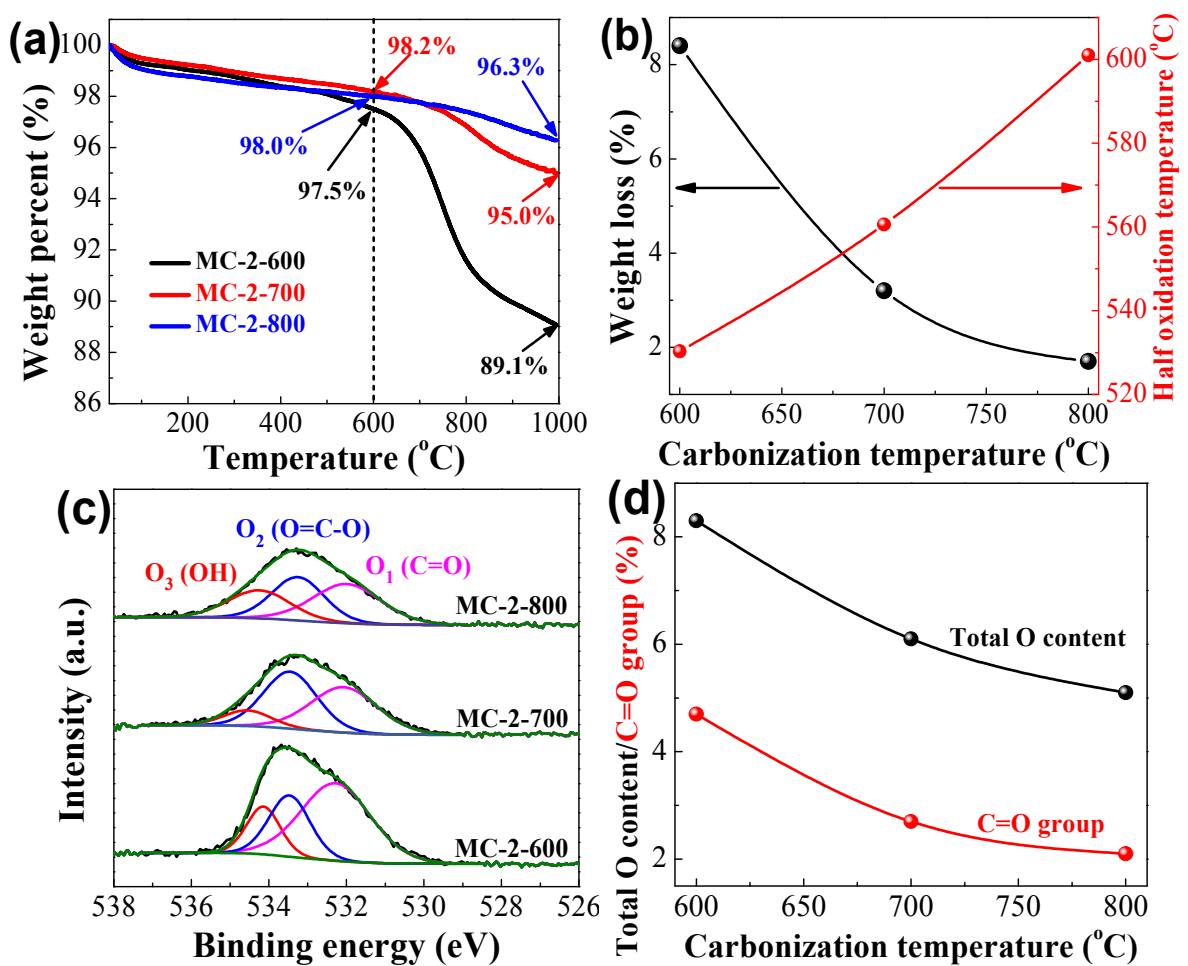

Fig. 3. (a) TG curves of MC-2-y; (b) Weight loss and half oxidation temperature of MC-2-y as a function of carbonization temperature; (c) 0 1s XPS spectra of MC-2-y; (d) Total oxygen and C=0 group contents of MC-2-y as a function of carbonization temperature.

tent of oxygenated functional groups on MCs could be modulated by controlling the carbonization temperature.

\subsection{Catalytic performance}

The PDH over the MCs were tested under the same conditions ( $0.2 \mathrm{~g}$ catalyst, $600{ }^{\circ} \mathrm{C}$, and $\left.20 \mathrm{~mL} / \mathrm{min}\right)$. The catalytic black test revealed that almost no propane conversion could be detected at $600{ }^{\circ} \mathrm{C}$. Fig. 4(a) shows the propane conversion and propylene selectivity of MCs, and the corresponding propylene yields are shown in Fig. S7. MC-0-600 shows a very low catalytic activity ( $\sim \%$ propane conversion). However, MC-1-600, MC-2-600, MC-3-600, and MC-4-600 exhibit much higher catalytic activities. In particular, MC-2-600 displays the highest initial propane conversion of $35.7 \%$ (the initial activities of MC-3-600, MC-1-600, and MC-4-600 are 35.5\%, 28.7\%, and $25.9 \%$, respectively). Over a period of $600 \mathrm{~min}$ on stream, the catalytic activities of MC-2-600, MC-3-600, MC-1-600, and MC-4-600 decreased to $28.1 \%, 27.6 \%, 23.4 \%$, and $21.0 \%$, respectively. This result indicates that the MCs with better porous ordering exhibit higher catalytic activity. Noticeably, all the MCs possess high propylene selectivity $(>90 \%)$ after $600 \mathrm{~min}$ time

Table 2

Weight losses and surface oxygenated functional groups of MCs.

\begin{tabular}{lccccc}
\hline Sample & $\begin{array}{c}\text { Weight loss } \\
(\%)\end{array}$ & $\begin{array}{c}\text { Total 0 } \\
\text { content (at\%) }\end{array}$ & $\begin{array}{c}\text { 01 } \\
\text { (at\%) }\end{array}$ & $\begin{array}{c}\text { 02 } \\
\text { (at\%) }\end{array}$ & $\begin{array}{c}\text { O3 } \\
\text { (at\%) }\end{array}$ \\
\hline MC-2-600 & 8.4 & 8.3 & 4.7 & 2.2 & 1.4 \\
MC-2-700 & 3.2 & 6.1 & 3.0 & 2.4 & 0.7 \\
MC-2-800 & 1.7 & 5.1 & 2.1 & 1.7 & 1.3 \\
MCO-2-800 & 7.6 & 7.5 & 2.5 & 2.7 & 2.3 \\
\hline
\end{tabular}

on stream.

Fig. 4(b) shows the catalytic performance of MC-2-y carbonized at different temperatures. The catalytic activity of MC-2-y decreases with an increase in the carbonization temperature. The initial propane conversion of MC-2-600 (35.7\%) is much higher than those of MC-2-700 (22.8\%) and MC-2-800 (14.9\%). During $600 \mathrm{~min}$ time on stream, propane conversions of MC-2-600, MC-2-700, and MC-2-800 decreased to 28.1\%, $18.9 \%$, and $14.0 \%$, respectively. Meanwhile, the propylene selectivity of MC-2-y increased with increasing carbonization temperature; the propylene selectivities of MC-2-600, MC-2-700, and MC-2-800 are 85.6\%, 88.7\%, and 93.5\%, respectively. This result demonstrates that the carbonization temperature can significantly affect the catalytic performance of carbon catalysts.

\subsection{Discussion}

\subsubsection{Effect of mesopore ordering}

It is known that the structural properties of mesoporous carbons are remarkably dependent on the self-assembly between resorcinol-formaldehyde resin and Pluronic F127. When the synthesis is carried out without Pluronic F127, almost no mesopores are formed, as demonstrated by $\mathrm{N}_{2}$ sorption results of MC-0-600 in Fig. 1. Therefore, almost no available active sites are accessible during the catalytic reaction [21,22]. MC-0-600 exhibits a very low catalytic activity in PDH (Fig. 4(a)). With the addition of Pluronic F127, a large number of pores are introduced into the carbon materials, which increases the surface area considerably (as proven by $\mathrm{N}_{2}$ sorption results and TEM 

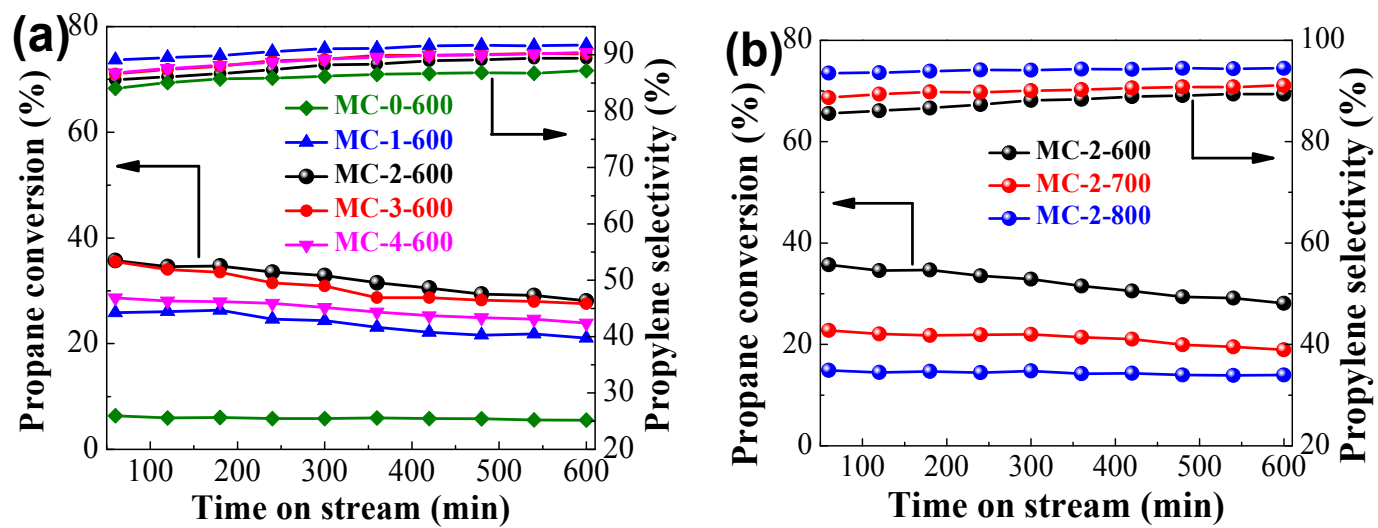

Fig. 4. Propane conversion and propylene selectivity as a function of time on stream over MC- $x-600$ (a) and MC-2-y (b).

images), and thus a large amount of surface active sites are available for the reaction. Therefore, MC-1-600, MC-2-600, MC-3-600, and MC-4-600 exhibited enhanced catalytic activity (Fig. 4(a)). Fig. 5(a) shows the specific activity and propane conversion of MCs as a function of formaldehyde/resorcinol ratio, which exhibit a volcano variation tendency. In particular, MC-2-600 and MC-3-600 exhibit much higher catalytic activities than those of MC-1-600 and MC-4-600, in good agreement with earlier studies that demonstrated that unique mesopores are favorable for mass transfer and can provide more active sites for the reaction [29,49-51]. For comparison, activated carbon $\left(920 \mathrm{~m}^{2} / \mathrm{g}\right)$ with many micropores was tested for PDH; it exhibited a high initial catalytic activity but low stability (Fig. S8). During 600 min time on stream, the propane conversion of activated carbons decreased from $30.6 \%$ to $6.0 \%$. According to a previous investigation on the adsorption equilibrium, the
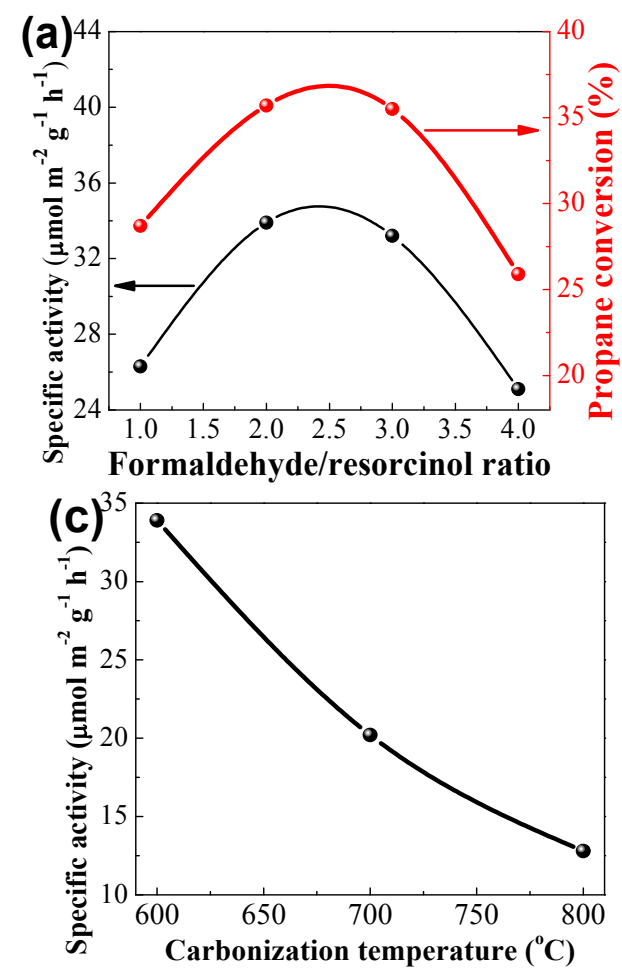

$\mathrm{C}_{3} \mathrm{H}_{6}$ adsorption on micro/mesoporous materials mainly depends on Knudsen diffusivity, which is calculated using the equation, $D_{\mathrm{k}}=9700 r_{\mathrm{p}}(T / M)^{1 / 2}\left(r_{\mathrm{p}}\right.$ is the pore radius, $M$ is the molecular weight of the adsorbate, and $T$ is the temperature) [52]. MCs with a large pore radius possess large $D_{\mathrm{k}}$ for $\mathrm{C}_{3} \mathrm{H}_{6}$ diffusion, which is favorable for the transfer of product $\mathrm{C}_{3} \mathrm{H}_{6}$ molecules outside the pores. Therefore, the MCs have much higher catalytic stability than activated carbons.

\subsubsection{Effect of carbonization temperature}

Carbon materials possess many surface oxygenated functional groups such as ketone, carboxylic anhydride, lactone, carboxylic acid, ether, and phenol [42-46]. Table S1 lists the decomposition temperatures of these oxygenated functional groups from previous. After carbonization at temperatures between 600 and $800{ }^{\circ} \mathrm{C}$, the main oxygenated functional
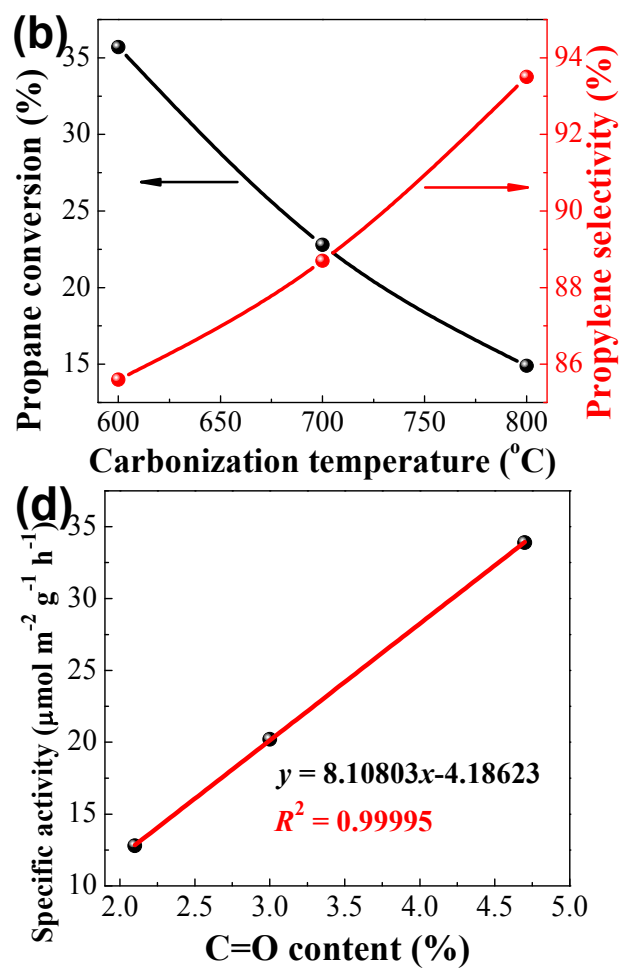

Fig. 5. (a) Specific activity and propane conversion of MC- $x-600$ as a function of formaldehyde/resorcinol ratio; Propane conversion, propylene selectivity (b), and specific activity (c) of MC-2-y as a function of carbonization temperature; (d) Specific activity of MC-2-y as a function of C=0 content. 
groups in MCs are $\mathrm{C}=\mathrm{O}, \mathrm{O}=\mathrm{C}-\mathrm{O}$, and $\mathrm{OH}$ groups (Fig. $3(\mathrm{c}$ )). Particularly, the concentrations of these functional groups can be controlled by adjusting the carbonization temperature (Fig. 3(c), Fig. 3(d), and Table 2). As shown in Fig. 5(b), the changes in the surface oxygen-containing groups would significantly influence the catalytic performance of carbon catalysts. More specifically, the catalytic activity of MCs decreases with increasing carbonization temperature, while the propylene selectivity increases with increasing carbonization temperature. At a low carbonization temperature of $600{ }^{\circ} \mathrm{C}$, the presence of acidic sites such as $\mathrm{O}=\mathrm{C}-\mathrm{O}$ groups would hinder propylene desorption and lead to deep cracking $[53,54]$. With an increase in the carbonization temperature to 700 and $800{ }^{\circ} \mathrm{C}$, an increasing number of $\mathrm{O}=\mathrm{C}-\mathrm{O}$ groups are decomposed, resulting in an increase in the propylene selectivity. The specific activity as a function of carbonization temperature indicates that the propylene formation rates decrease with an increase in the carbonization temperature (Fig. 5(c)), owing to the decrease in surface active sites.

\subsubsection{The role of surface oxygenated functional groups}

Carbonyl $(\mathrm{C}=0)$ groups are proposed to be the active sites in the oxidative dehydrogenation over carbon catalysts [12-16]. According to a recently reported catalytic mechanism, butane molecules were catalyzed by two $\mathrm{C}=0$ groups and each $\mathrm{C}=\mathrm{O}$ group provided a single electron to graphene acting as the reservoir. Then, the residual hydrogen atoms reacted with the surrounding $\mathrm{O}$ from water, thus closing the oxidative dehydrogenation cycle [12]. Unlike oxidative dehydrogenation, direct dehydrogenation occurs in a condition without oxygen agents. In recent studies on carbon catalysts in direct dehydrogenation,
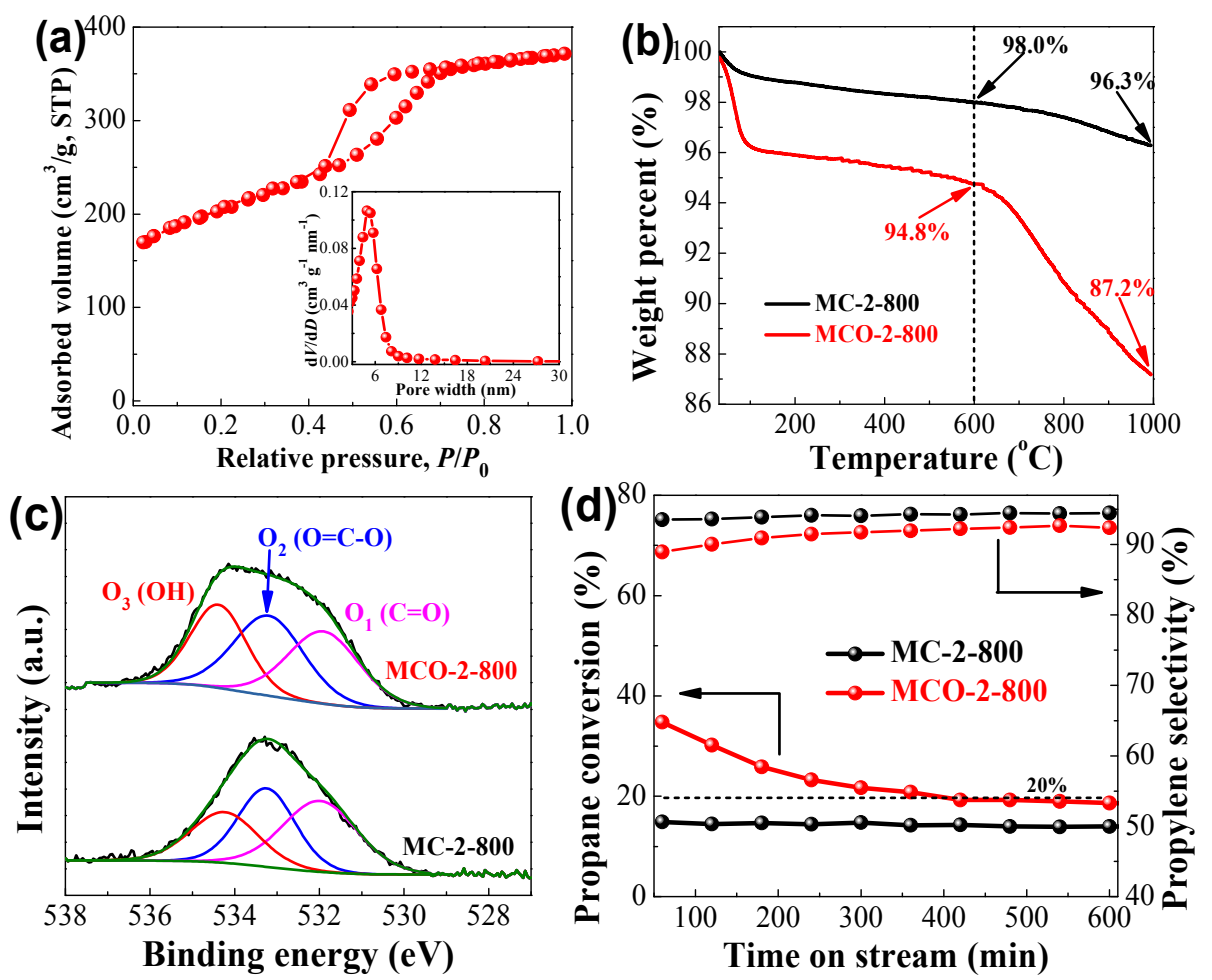

the active sites and catalytic mechanisms are still not totally identified [18-22,33-35]. In general, defects, heteroatoms, and surface oxygenated functional groups are regarded as the active sites for direct dehydrogenation reaction.

Herein, mesoporous carbons with highly ordered mesoporous structures were obtained by carbonization at three different temperatures $\left(600,700\right.$, and $\left.800{ }^{\circ} \mathrm{C}\right)$, and the concentration of $\mathrm{C}=\mathrm{O}$ groups could be controlled well by adjusting the carbonization temperature (Fig. 3). Further, the excellent linear relationship between the $\mathrm{C}=0$ groups and specific activity was established (Fig. 5(d)), while no obvious linear relationship between the $\mathrm{O}=\mathrm{C}-\mathrm{O}$ and $\mathrm{OH}$ groups and specific activity was found (Fig. S9), confirming that the $\mathrm{C}=0$ groups are the most possible active sites on carbon materials in $\mathrm{PDH}$.

To verify the important role of oxygenated functional groups, MC-2-800 was further oxidized with $\mathrm{HNO}_{3}$ to obtain MCO-2-800. As shown in Fig. 6(a), there is no obvious change in the structural properties of MCO-2-800 compared to those of the parent material. The TG curves (Fig. 6(b)) and 0 1s XPS spectra (Fig. 6(c)) reveal an obvious increase in the oxygenated functional groups: while the weight losses for MC-2-800 and MCO-2-800 are $1.7 \%$ and $7.6 \%$, respectively, the 0 concentrations of MC-2-800 and MCO-2-800 are 5.1\% and 7.5\%, respectively. The results of propane conversion catalyzed by MCO-2-800 indicate its enhanced catalytic activity, demonstrating that the active sites of MCs in PDH are oxygenated functional groups. During the $\mathrm{HNO}_{3}$ oxidation process, many oxygenated functional groups such as $\mathrm{OH}, \mathrm{O}=\mathrm{C}-\mathrm{O}$, and $\mathrm{C}=\mathrm{O}$ groups could be introduced onto the mesoporous carbon. The presence of $\mathrm{O}=\mathrm{C}-\mathrm{O}$ groups would result in cracking and lower propylene selectivity $[31,35]$. However, the $\mathrm{O}=\mathrm{C}-\mathrm{O}$ groups are

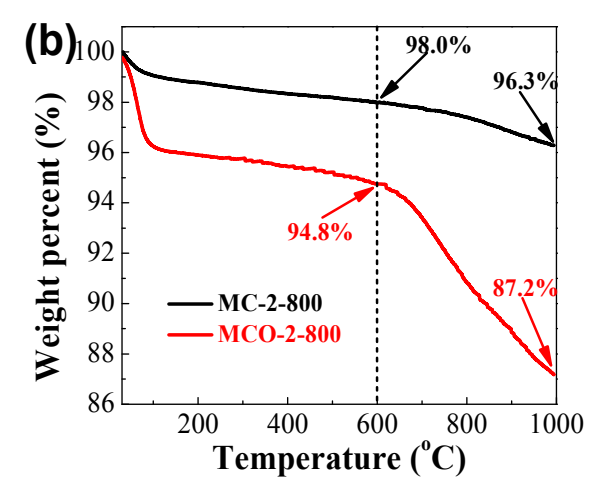

Fig. 6. (a) $\mathrm{N}_{2}$ adsorption-desorption isotherms and the corresponding pore size distribution curve (inset) of MCO-2-800; TGA curves (b), 0 1s XPS spectra (c), and catalytic performances (d) of MC-2-800 and MCO-2-800. 
unstable and would decompose during the PDH reaction at the reaction temperature of $600{ }^{\circ} \mathrm{C}$ [42]. As shown in Fig. 6(d), the activity of MCO-2-800 decreased obviously. After $600 \mathrm{~min}$ time-on-stream, the catalytic activity of MCO-2-800 decreased from $34.7 \%$ to $18.6 \%$. As shown in Table 2 , the $\mathrm{C}=0$ concentration of MCO-2-800 is $\sim 2.5 \%$, which is slightly higher than that of MC-2-800 (2.1\%). This result is in good agreement with their catalytic performance after $600 \mathrm{~min}$ time-on-stream (MCO-2-800 (propane conversion: 18.6\%, propylene selectivity: $92.4 \%$ ) and MC-2-800 (propane conversion: $14.0 \%$, propylene selectivity: $94.5 \%$ )), further indicating that $\mathrm{C}=0$ groups are the most possible active sites in carbon materials during PDH.

On the basis of above characterizations and catalytic tests, it can be concluded that the $\mathrm{C}=0$ groups on the MCs are the most possible active sites for PDH. The formaldehyde/resorcinol ratio and carbonization temperature can influence the mesoporous ordering and surface concentrations of $\mathrm{C}=\mathrm{O}$ groups of MCs, and thus, they influence the catalytic performance of MCs in PDH. As demonstrated in this study, mesoporous carbons with a highly ordered mesoporous structure and rich $\mathrm{C}=\mathrm{O}$ groups would exhibit high catalytic performance in PDH.

\section{Conclusions}

Mesoporous carbons with different pore orderings were prepared by a controlled surfactant-assisted method, and they exhibit much higher catalytic performance than those of their nonporous counterparts in propane dehydrogenation. This is because, owing to their high surface area, mesoporous carbons can provide a large amount of surface active sites for the reaction. Particularly, the mesopore ordering can affect the catalytic performance of carbon materials. The highly ordered structures of mesoporous carbons are good for mass transportation and have more accessible active sites. Thus, mesoporous carbons with better pore ordering exhibit higher catalytic performance. Furthermore, the carbonization temperature can affect the catalytic performance of carbon catalysts. The number of surface oxygenated functional groups of mesoporous carbons decreases with an increase in the carbonization temperature. The specific activities (initial propylene formation rate) of these mesoporous carbons have an excellent linear relationship with the surface concentrations of $\mathrm{C}=0$ groups, indicating that the $\mathrm{C}=0$ groups are the most possible active sites for $\mathrm{PDH}$. This study is instructive for the design and synthesis of carbon-based catalysts with controlled structures and surface functional groups for various reactions including propane dehydrogenation.

\section{Acknowledgments}

This work was supported by the National Natural Science Foundation of China (21421001, 21573115), the Fundamental Research Funds for the Central Universities (63185015), and the Foundation of State Key Laboratory of High-efficiency Utilization of Coal and Green Chemical Engineering (2017-K13).

\section{References}

[1] D. S. Su, S. Perathoner, G. Centi, Chem. Rev., 2013, 113, 5782-5816.

[2] M. M. Titirici, R. J. White, N. Brun, V. L. Budarin, D. S. Su, F. del Monte, J. H. Clark, M. J. MacLachlan, Chem. Soc. Rev., 2015, 44, 250-290.

[3] W. Qi, P. Yan, D. S. Su, Acc. Chem. Res., 2018, 51, 640-648.

\section{Graphical Abstract}

Chin. J. Catal., 2019, 40: 1385-1394 doi: S1872-2067(19)63334-6

Mesoporous carbons as metal-free catalysts for propane dehydrogenation: Effect of the pore structure and surface property

Zhong-Pan Hu, Jin-Tao Ren, Dandan Yang, Zheng Wang, Zhong-Yong Yuan*

Nankai University; Ningxia University

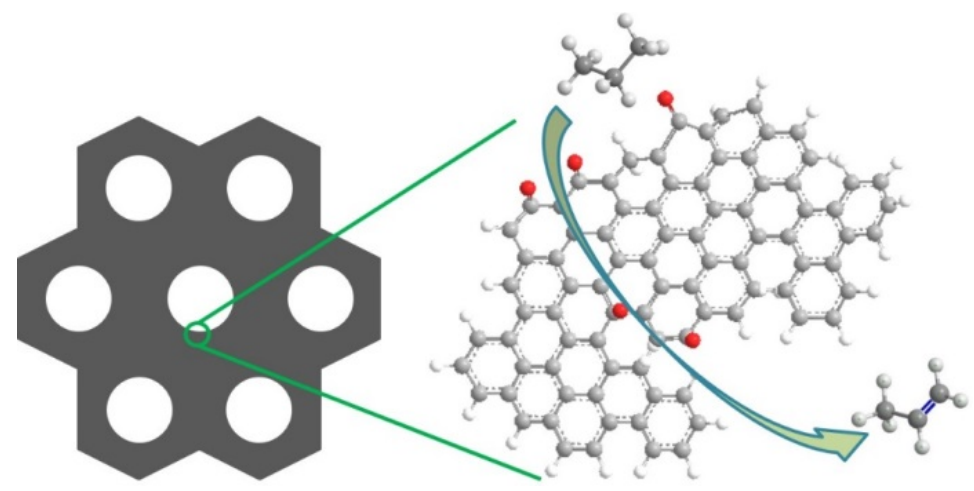

Mesoporous carbons with different pore ordering and concentrations of surface oxygenated functional groups were synthesized and used as metal-free catalysts for direct dehydrogenation of propane to propylene. 
[4] J. J. H. B. Sattler, J. Ruiz-Martinez, E. Santillan-Jimenez, B. M. Weckhuysen, Chem. Rev., 2014, 114, 10613-10653.

[5] L. Liu, Y. P. Zhu, M. Su, Z. Y. Yuan, ChemCatChem, 2015, 7, 2765-2787.

[6] Z. Zhao, G. Ge, W. Li, X. Guo, G. Wang, Chin. J. Catal., 2016, 37, 644-670.

[7] Y. P. Zhu, Y. Liu, Y. P. Liu, T. Z. Ren, T. Chen, Z. Y. Yuan, ChemCatChem, 2015, 7, 2903-2909.

[8] Q. Wang, Z. Zhang, M. Wang, J. Li, J. Fang, Y. Lai, Chin. J. Catal., 2018, 39, 1210-1218.

[9] G. Wen, S. Wu, B. Li, C. Dai, D. S. Su, Angew. Chem. Int. Ed., 2015, 54, 4105-4109.

[10] A. Sedrpoushan, M. Heidari, O. Akhavan, Chin. J. Catal., 2017, 38, 745-757.

[11] L. Liu, S. D. Xu, F. Y. Wang, Y. J. Song, J. Liu, Z. M. Gao, Z. Y. Yuan, RSC Adv., 2017, 7, 12524-12533.

[12] J. Zhang, X. Liu, R. Blume, A. Zhang, R. Schlögl, D. S. Su, Science, 2008, 322, 73-77.

[13] C. Liang, H. Xie, V. Schwartz, J. Howe, S. Dai, S. H. Overbury, J. Am. Chem. Soc., 2009, 131, 7735-7741.

[14] X. Liu, B. Frank, W. Zhang, T. P. Cotter, R. Schlögl, D. S. Su, Angew. Chem. Int. Ed., 2011, 50, 3318-3322.

[15] J. Zhang, D. S. Su, R. Blume, R. Schlögl, R. Wang, X. Yang, A. Gajović, Angew. Chem. Int. Ed., 2010, 49, 8640-8644.

[16] W. Qi, W. Liu, B. Zhang, X. Gu, X. Guo, D. Su, Angew. Chem. Int. Ed., 2013, 52, 14224-14228.

[17] W. Qi, W. Liu, X. Guo, R. Schlögl, D. Su, Angew. Chem. Int. Ed., 2015, 54, 13682-13685.

[18] Z. Zhao, Y. Dai, G. Ge, Catal. Sci. Technol., 2015, 5, 1548-1557.

[19] Z. Zhao, Y. Dai, G. Ge, X. Guo, G. Wang, Green Chem., 2015, 17, 3723-3727.

[20] Z. Zhao, Y. Dai, G. Ge, G. Wang, AIChE J., 2015, 61, 2543-2561.

[21] Z. P. Hu, L. F. Zhang, Z. Wang, Z. Y. Yuan, J. Chem. Technol. Biotechnol, 2018, 93, 3410-3417.

[22] Z. P. Hu, H. Zhao, C. Chen, Z. Y. Yuan, Catal. Today, 2018, 316, 214-222

[23] P. Poudel, Q. Qiao, Nano Energy, 2014, 4, 157-175.

[24] M. Chen, L. L. Shao, X. Qian, L. Liu, T. Z. Ren, Z. Y. Yuan, Chem. Eng. J., 2014, 256, 23-31.

[25] L. L. Shao, M. Chen, Z. Y. Yuan, J. Power Sources, 2014, 272, 1091-1099.

[26] C. Chen, H. Wang, C. Han, J. Deng, J. Wang, M. Li, M. Tang, H. Jin, Y. Wang, J. Am. Chem. Soc., 2017, 139, 2657-2663.

[27] J. Deng, T. Xiong, F. Xu, M. Li, C. Han, Y. Gong, H. Wang, Y. Wang, Green Chem., 2015, 17, 4053-4060.

[28] J. Goscianska, R. Pietrzak, J. Matos, Catal. Today, 2018, 301, 204-216.
[29] J. Matos, J. Laine, Appl. Catal. A, 2003, 241, 25-38.

[30] J. Zhang, D. Su, A. Zhang, D. Wang, R. Schlögl, C. Hébert, Angew. Chem. Int. Ed., 2007, 46, 7319-7323.

[31] D. S. Su, J. J. Delgado, X. Liu, D. Wang, R. Schlögl, L. Wang, Z. Zhang, Z. Shan, F. S. Xiao, Chem. Asian J., 2009, 4, 1108-1113.

[32] Y. Song, G. Liu, Z. Y. Yuan, RSC Adv., 2016, 6, 94636-94642.

[33] L. Li, W. Zhu, Y. Liu, L. Shi, H. Liu, Y. Ni, S. Liu, H. Zhou, Z. Liu, RSC Adv., 2015, 5, 56304-56310.

[34] T. Y. Ma, L. Liu, Z. Y. Yuan, Chem. Soc. Rev., 2013, 42, 3977-4003.

[35] L. Liu, Q. F. Deng, B. Agula, X. Zhao, T. Z. Ren, Z. Y. Yuan, Chem. Commun., 2011, 47, 8334-8336.

[36] L. Liu, Q. F. Deng, B. Agula, T. Z. Ren, Y. P. Liu, B. Zhaorigetu, Z. Y. Yuan, Catal. Today, 2012, 186, 35-41.

[37] C. Liang, S. Dai, J. Am. Chem. Soc., 2006, 128, 5316-5317.

[38] L. Liu, F. Y. Wang, G. S. Shao, Z. Y. Yuan, Carbon, 2010, 48, 2089-2099.

[39] D. Liu, J. H. Lei, L. P. Guo, D. Qu, Y. Li, B. L. Su, Carbon, 2012, 50, 476-487.

[40] M. Kruk, M. Jaroniec, Chem. Mater., 2001, 13, 3169-3183.

[41] J. C. Groen, L. A. A. Peffer, J. Pérez-Ramírez, Microporous Mesoporous Mater., 2003, 60, 1-17.

[42] J. L. Figueiredo, M. F. R. Pereira, M. M. A. Freitas, J. J. M. Orfao, Carbon, 1999, 37, 1379-1389.

[43] J. L. Figueiredo, M. F. R. Pereira, M. M. A. Freitas, J. J. M. Órfão, Ind. Eng. Chem. Res., 2007, 46, 4110-4115.

[44] V. Datsyuk, M. Kalyva, K. Papagelis, J. Parthenios, D. Tasis, A. Siokou, I. Kallitsis, C. Galiotis, Carbon, 2008, 46, 833-840.

[45] S. Kundu, Y. Wang, W. Xia, M. Muhler, J. Phys. Chem. C, 2008, 112, 16869-16878.

[46] G. Hotová, V. Slovák, O. S. G. P. Soares, J. L. Figueiredo, M. F. R. Pereira, Carbon, 2018, 134, 255-263.

[47] G. Wen, J. Diao, S. Wu, W. Yang, R. Schlögl, D. S. Su, ACS Catal., 2015, 5, 3600-3608.

[48] W. Qi, W. Liu, B. Zhang, X. Gu, X. Guo, D. Su, Angew. Chem. Int. Ed., 2013, 52, 14224-14228.

[49] H. Li, Y. Sun, Z. Y. Yuan, Y. P. Zhu, T. Y. Ma, Angew. Chem. Int. Ed., 2018, 57, 3222-3227.

[50] Y. Wang, H. Zhao, G. Zhao, Appl. Catal. B, 2015, 164, 396-406.

[51] H. Ma, L. Zeng, H. Tian, D. Li, X. Wang, X. Li, J. Gong, Appl. Catal. $B, 2016,181,321-331$.

[52] C. A. Grande, A. E. Rodrigues, Ind. Eng. Chem. Res., 2001, 40, 1686-1693.

[53] N. Rahimi, R. Karimzadeh, Appl. Catal. A, 2011, 398, 1-17.

[54] Z. P. Hu, C. Chen, J. T. Ren, Z. Y. Yuan, Appl. Catal. A, 2018, 559, 85-93.

\title{
介孔碳作为非金属丙烷脱氢催化剂: 孔道结构和表面性质的影响
}

\author{
胡忠攀 ${ }^{\mathrm{a}}$ ，任金涛 ${ }^{\mathrm{a}}$ ，杨丹丹 ${ }^{\mathrm{a}}$ ，王 政 ${ }^{\mathrm{b}}$ ，袁忠勇 ${ }^{\mathrm{a}}{ }^{*}$ \\ a南开大学材料科学与工程学院, 先进能源材料化学教育部重点实验室, 天津 300350

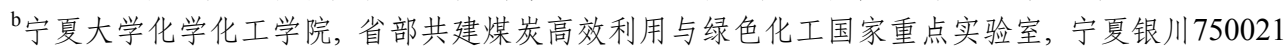

\begin{abstract}
摘要: 作为一种非金属催化剂, 纳米碳材料被广泛应用于各种催化反应. 尤其在近几年, 纳米碳材料被发现是一种良好的 烷烃脱氢催化剂. 但是, 由于缺乏对碳材料的结构和表面性质方面的基础研究, 碳材料在烷烃直接脱氢反应中的活性位点 并不明确. 另外, 由于碳材料本身的复杂结构, 精确调控碳材料的微观孔道结构, 研究碳材料的结构特性对其烷烃脱氢反 应性能的影响仍存在较大难度. 本文利用软模板和控制焙烧的方法合成出一系列具有不同孔道有序性和表面性质的介孔 碳材料, 系统研究了介孔碳孔道有序性和表面含氧官能团种类、含量等因素对介孔碳材料丙烷脱氢性能的影响.
\end{abstract}


XRD, SEM, TEM和氮气吸附结果显示, 通过添加F127可将介孔孔道引入到碳材料中; 调节间苯二酚和甲醛的比例可 以实现介孔碳材料孔道有序性的调控; 在保证碳材料孔道有序性的前提下, 通过控制焙烧温度可以精确调节碳材料表面 的含氧官能团种类和数量. 然后, 将该系列碳基催化剂进行丙烷脱氢测试. 结果发现, 介孔的引入可以为丙烷脱氢反应提 供大量的活性位点, 因而介孔碳比无孔碳具有更加优异的丙烷脱氢活性. 对于介孔碳材料, 孔道越有序, 表面含氧官能团 越多的介孔碳材料表现出更加优异的丙烷脱氢性能. 因为高度有序的介孔孔道有利于反应物和反应产物的传质, 降低催 化反应的空间位阻, 从而提高催化剂的活性, 选择性和稳定性. 碳材料表面的含氧官能团被认为是丙烷脱氢的主要活性位 点, 含氧官能团越多, 活性位点越多, 因而活性就越好. 但是, 介孔碳表面含有各种不同的含氧官能团(羧基、羟基和碳基). 结合XPS和丙烷脱氢测试结果, 将不同温度处理后的有序介孔碳的丙烯生成速率和表面含氧官能团含量进行拟合. 结果表 明, 介孔碳材料表面的羰基含量与其丙烯生成速率之间具有非常好的线性关系, 而羧基和羟基含量与丙烯生成速率之间并 不具有明显的线性关系, 从而证明碳材料表面的碳基可能为其在丙烷脱氢反应中的活性位点. 本文从实验角度为纳米碳 材料在烷烃脱氢方面的活性位点进行了初步证明.

关键词: 介孔碳; 丙烷; 脱氢; 丙烯; 无金属催化

收稿日期: 2019-01-20. 接受日期: 2019-02-25. 出版日期: 2019-09-05.

*通讯联系人. 电话/传真: (022)23509610; 电子信箱: zyyuan@nankai.edu.cn

基金来源：国家自然科学基金(21421001，21573115); 中央高校基本科研业务费专项资金(63185015); 煤炭高效利用与绿色化工 国家重点实验室基金(2017-K13).

本文的电子版全文由Elsevier出版社在ScienceDirect上出版(http://www.sciencedirect.com/science/journal/18722067). 